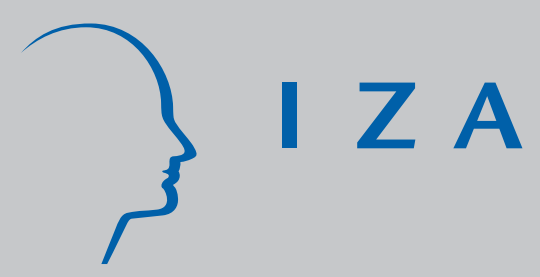

IZA DP No. 2467

Can Subjective Mortality Expectations and Stated Preferences Explain Varying Consumption and Saving Behaviors among the Elderly?

Martin Salm

November 2006 


\title{
Can Subjective Mortality Expectations and Stated Preferences Explain Varying Consumption and Saving Behaviors among the Elderly?
}

\author{
Martin Salm \\ MEA, University of Mannheim
}
Discussion Paper No. 2467
November 2006

\author{
IZA \\ P.O. Box 7240 \\ 53072 Bonn \\ Germany \\ Phone: +49-228-3894-0 \\ Fax: +49-228-3894-180 \\ E-mail: iza@iza.org
}

\begin{abstract}
Any opinions expressed here are those of the author(s) and not those of the institute. Research disseminated by IZA may include views on policy, but the institute itself takes no institutional policy positions.

The Institute for the Study of Labor (IZA) in Bonn is a local and virtual international research center and a place of communication between science, politics and business. IZA is an independent nonprofit company supported by Deutsche Post World Net. The center is associated with the University of Bonn and offers a stimulating research environment through its research networks, research support, and visitors and doctoral programs. IZA engages in (i) original and internationally competitive research in all fields of labor economics, (ii) development of policy concepts, and (iii) dissemination of research results and concepts to the interested public.
\end{abstract}

IZA Discussion Papers often represent preliminary work and are circulated to encourage discussion. Citation of such a paper should account for its provisional character. A revised version may be available directly from the author. 
IZA Discussion Paper No. 2467

November 2006

\section{ABSTRACT \\ Can Subjective Mortality Expectations and Stated Preferences Explain Varying Consumption and Saving Behaviors among the Elderly?*}

This study investigates how subjective mortality expectations and heterogeneity in time and risk preferences affect the consumption and saving behavior of the elderly. Previous studies find that the large wealth disparities observed among the elderly cannot be explained by differences in preferences. In contrast, this study identifies a strong relationship between answers to survey questions about time and risk preferences and consumption and saving behaviors. This paper uses data on information about preferences and subjective mortality expectations from the Health and Retirement Study merged with detailed consumption data from two waves of the Consumption and Activities Mail Survey. The main results are: 1) consumption and saving choices vary with subjective mortality rates in a way that is consistent with the life cycle model; 2) different answers to survey questions about time and risk preferences reflect differences in actual saving and consumption behavior; and 3) there is substantial heterogeneity in estimated time discount rates and risk aversion parameters.

JEL Classification: D81, D91, J14

Keywords: preferences, mortality expectations, saving decisions

Corresponding author:

Martin Salm

MEA

University of Mannheim

L13, 17

68131 Mannheim

Germany

E-mail: salm@mea.uni-mannheim.de

I thank Han Hong, Ahmed Khwaja, Daniel Schunk, Frank Sloan, Alessandro Tarozzi, and Curtis Taylor for helpful advice. I also thank seminar participants at Duke U, U Conn, Baylor U, UNC Greensboro, HEC Lausanne, and the Netspar Workshop in Utrecht for valuable suggestions. 


\section{Introduction}

This study investigates how subjective mortality expectations and heterogeneity in time and risk preferences affect the consumption and saving behavior of the elderly. Whether or not such preferences are heterogeneous has important policy implications, e.g. for analyzing the effects of tax incentives for saving (Bernheim 2002). However, the role of heterogeneous preferences in explaining differences in saving and consumption behaviors is still disputed. Some previous studies find that differences in preferences play no role in explaining wealth differences (Bernheim, Skinner, and Weinberg 2001, Dynan, Skinner, and Zeldes 2004). In contrast, evidence from survey questions suggests that there might be substantial differences in time and risk preferences between individuals (Barsky, Juster, Kimball and Shapiro 1997, Harrison, Lau and Williams 2002, Kapteyn and Teppa 2003). Though, it is not a priori clear how answers to survey questions relate to actual intertemporal consumption choices ${ }^{1}$. This study identifies a strong relationship between answers to survey questions about time and risk preferences and saving and consumption behavior.

The lifecycle model, which goes back to the pioneering work of Modigliani and Brumberg (1954) and Yaari (1965), predicts a specific relationship between consumption growth, subjective mortality expectations and time and risk preference parameters. At the core of the lifecycle model is the idea that forward looking agents hold the ex-ante expected marginal utility from consumption constant across periods. This implies that agents with higher subjective mortality rates should allocate less money for future as opposed to present consumption, because they are less likely to benefit from it. Therefore, the growth rate of consumption should be lower (or the decline in consumption faster) for individuals with higher subjective mortality rates. The magnitude of this effect will depend on agents' risk aversion. More risk-averse agents are less willing to accept fluctuations in consumption. Further, agents with a higher discount factor of future consumption should allocate more

\footnotetext{
${ }^{1}$ The study by Harrison, Lau, and Williams (2002) links answers to survey questions to real monetary rewards.
} 
funds to present consumption, which implies that the growth rate of consumption will be lower.

The restrictions imposed by the lifecycle model allow the estimation of time discount rates and risk aversion parameters from observed consumption and saving choices. I estimate Euler equations that relate consumption growth to subjective mortality rates and the risk of medical expenses. Including the risk of medical expenses allows for a precautionary savings motive. I control for agents that are credit constrained or buffer-stock savers. The data I use merge information about preferences and subjective mortality expectations from the Health and Retirement Study with detailed consumption data from two waves of the Consumption and Activities Mail Survey. The combination of subjective mortality rates, detailed consumption data, and answers to survey information about time and risk preferences allow a new approach to identifying heterogeneous preference parameters.

Several previous studies examine the effect of life table mortality rates on consumption and saving behaviors (Skinner 1985, Hurd 1989, Palumbo 1999, Bloom, Canning, and Graham 2003, De Nardi, French, and Jones 2005). However, individual mortality probabilities differ from life table mortality rates. If differences between individual mortality probabilities and life table mortality rates are correlated with other determinants of consumption choice, such as time preferences and risk aversion, then estimates using life table mortality rates might lead to biased estimation results ${ }^{2}$. For example, smokers tend to have higher mortality probabilities than non-smokers, and they also tend to differ in their risk aversion and time preferences (Khwaja, Sloan, and Salm 2006). An alternative to using life table mortality rates is to use subjective mortality expectations. Previous studies find that subjective mortality probabilities vary with known predictors of mortality such as smoking, income, and education, and are on average remarkably good predictors of actual mortality

\footnotetext{
${ }^{2}$ Skinner (1985) and DeNardi, French and Jones (2005) adjust mortality rates for occupation and wealth, respectively.
} 
(Hamermesh 1985, Hurd and McGarry 1995, 2002, Smith, Taylor, and Sloan 2001, Khwaja, Sloan, and Chung 2005) $)^{3}$. Gan, Gong, Hurd, and McFadden (2004) use subjective mortality probabilities to estimate a structural model of saving and consumption that includes a bequest motive. They find that estimates using subjective expectations fit the data better than estimates that are based on life table mortalities. In contrast to their study, I include a precautionary savings motive for health care expenditures and use detailed consumption data instead of predicting wealth levels.

The shortage of high quality longitudinal consumption data has long presented a major difficulty for studying saving and consumption behavior. Many previous studies either use information on food consumption only, which is included in some commonly used panel datasets, or calculate consumption from differences in wealth levels between periods (see survey by Lusardi and Browning 1996). However, food consumption might not be a good proxy for overall consumption (Attanasio and Weber 1995, Lusardi and Browning 1996), and changes in assets can be an imprecise measure of consumption. Other studies create pseudopanels from cross-sectional data (Parker and Preston 2005). In this study I employ a measure of annual consumption spending on nondurable goods based on two waves of the Consumption and Activities Mail Survey, which was administered to a sub-sample of the Health and Retirement Study population in 2001 and 2003.

In order to examine whether varying saving and consumption behavior can be explained by heterogeneous time and risk preferences, it is necessary to identify individuals or groups of individuals with different preferences. Dynan, Skinner and Zeldes (2004) examine whether preferences vary by income groups. They find that for working age households saving rates increase with higher permanent income, but argue that higher saving rates of high income households cannot be explained by lower time discount rates and risk aversion, because in retirement the wealth of well to do households doesn't decline at a faster rate than

\footnotetext{
${ }^{3}$ Subjective probabilities also tend to be good predictors of events other than mortality (survey by Manski 2004).
} 
the wealth of poorer older households. However, an alternative explanation consistent with heterogeneous preferences could be that life expectancy is higher for wealthy individuals, which could justify slow rates of dis-saving in retirement among the wealthy. Bernheim, Skinner and Weinberg (2001) examine whether preferences vary by wealth levels. They argue that time preferences, subjective mortality rates, and risk aversion play no role in determining the distribution of retirement savings, because growth rates for food consumption do not vary systematically with wealth around retirement. However, changes in food consumption might not be a good measure of changes in overall consumption. Also, in the presence of a precautionary savings motive for medical expenditures the lifecycle model does not necessarily predict that wealthier households with low time discount factors have higher consumption growth rates than poorer households with high time discount factors, because the effect of lower time discount rates could be offset by the effect of a stronger precautionary savings motive for poorer households. In this study I examine whether consumption and saving behaviors vary with the answers to survey question on time and risk preferences. Barsky, Juster, Kimball and Shapiro (1997) and Kapteyn and Petta (2003) find that there is substantial variation in stated time and risk preferences, and Harrison, Lau and Williams (2002) find that answers to questions on time preferences are also heterogeneous if they are tied to real monetary rewards. To the author's knowledge, this is the first study that matches the answers to survey questions on time and risk preferences with detailed consumption data in order to study the effect of heterogeneous preferences on consumption behaviors.

The main results are: First, consumption and saving choices vary with subjective mortality rates and reported time and risk preferences in a way that is consistent with the life cycle model. This finding contributes to a debate about whether the saving and consumption behaviors of the elderly are consistent with the life-cycle model. Some studies cite the lack of (or slow pace of) asset decumulation among the elderly as evidence against the life-cycle model (Hurd 1987, Hurd 1990, Attanasio and Hoynes 2000). Whether consumption growth 
decreases with higher mortality expectations is an alternative and more direct test of the lifecycle model. Second, consumption growth varies with reported preferences in the predicted way. This finding suggests that different answers to survey questions about time and risk preferences reflect differences in actual saving and consumption behavior, and it adds credibility to studies that use survey questions to gain knowledge of preferences. Third, there is substantial heterogeneity in the estimated time discount rates and risk aversion parameters. Utility parameters for time and risk preferences are a critical input in analysis based on life cycle models, which are routinely used for a wide range of applications. Heterogeneous preferences can have implications e.g. for examining the effects of tax incentives on saving or for explaining the wealth distribution.

The paper proceeds as follows: Section 2 describes the data. Section 3 presents and discusses the identification strategy. The results are presented in section 4 . Section 5 concludes.

\section{Data description}

This study combines data from waves five and six of the Health and Retirement Study (HRS), which were collected in 2000 and 2002, with information from the Consumption and Activities Mail Survey (CAMS) from 2001 and 2003. The HRS is a national panel study, which started in 1992 and was repeated biannually. The sample in the year 2000 survey includes about 19,600 respondents. These include members of the original HRS cohort born between 1931 and 1941, as well as later additions to the HRS sample, which were drawn from those born before 1931 (AHEAD and CODA cohorts) and individuals born between 1942 and 1947 (War Baby cohort). The HRS also includes the spouses of all sample participants regardless of age. The HRS contains detailed information on health, income, assets, future expectations, as well as questions about attitudes and preferences. One shortcoming of the HRS as well as of other large U.S. household panel surveys is the lack of detailed information 
about household consumption. The only information about household consumption included in the main HRS survey concerns at home and out of home food consumption. The Consumption and Activities Mail Survey remedies this deficit and includes detailed information on household consumption spending, and also spending intentions. A description of the CAMS survey is provided in Butrica, Goldwin, and Johnson (2005). The CAMS questionnaire was sent to initially 5,000 households randomly drawn from the HRS population. 2,989 households completed both surveys in 2001 and 2003. I restrict the sample to persons who are above age 65 (because there are changes in consumption patterns around retirement, Aguar and Hurst 2005), and to single person households, which allows disregarding difficulties in modeling intra-household decision making. After excluding some observations with missing variables the estimation sample consists of 476 observations. The baseline regression, which also excludes constrained agents and some respondents with focal answers about mortality expectations from the sample, includes 371 observations.

The dependent variable is the real annual percentage change in consumption. I measure consumption as the sum of annual expenditures on nondurable goods, which include spending on food, gas, clothing, dining out, vacations, tickets to events, and hobbies. I calculate the yearly percentage change in consumption by taking the difference of the logarithms of consumption spending on nondurable goods in 2003 and 2001, divided by two. I compute real consumption growth rates by adjusting for the increase of the consumer price index for all goods. I exclude purchases of durable goods such as cars. Expenditures on durable goods do not coincide with the consumption flows received from them. Adjusting consumption flows from durable goods is also costly for consumers. The consumption variable also excludes medical expenditures. Medical care does typically not provide direct utility to consumers, but is an investment in health. For studying changes in consumption, the change in the consumption of nondurable goods is one of the best available measures (Lusardi and Browning 1996). Alternatively I also include a specification that is based on food 
consumption only. Table 1 shows that the annual real consumption growth for nondurable goods in the estimation sample is negative, while the expenditure on food consumption is growing.

Among the explanatory variables in my estimation is the subjective annual mortality rate. The HRS does not directly ask about subjective mortality probabilities in the following year, but it includes questions about subjective longevity probabilities. Specifically, the HRS asks about the percent chance that a respondent would live to age A, where A depends on the respondent's current age and is between 11 and 15 years above the respondent's current age. Previous studies have shown that subjective longevity probabilities are in general very good predictors of actual longevity (Hurd and McGarry 1995, 2002, Smith, Taylor, and Sloan 2001, and Khwaja, Sloan, and Chung 2005). However, the high frequency of focal answers raises concerns about the validity of self-reported longevity probabilities. In the 2000 HRS survey, $9.5 \%$ of respondents stated that their subjective longevity probability was $0 \%$ and $10.7 \%$ stated it was $100 \%$. Gan, Hurd, and McFadden (2003) suggest a procedure that involves adjusting stated probabilities based on actual mortality in the two years following the survey. I decided against correcting stated probabilities, because even somewhat unrealistic expectations might still be what agents base their decision on.

For calculating subjective mortality rates, I follow Gan, Hurd, and McFadden (2003) in assuming that subjective annual mortality rates $m_{i, t}$ are the product of annual life-table mortality rates $m_{0, t}$ and an individual specific individual mortality factor $\xi_{i}$ :

$$
m_{i, t}=\xi_{i} m_{o, t}
$$

I use life table mortality rates for 1998 separately for men and women which are provided by the Center for Disease Control (http://www.cdc.gov/nchs/nvsr48_18.pdf ). Given equation (1) the subjective probability $s_{i, a, A}$ of individual $i$ to survive from age $a$ to age $A$ can be written as: 


$$
s_{i, a, A}=\prod_{t=a}^{A-1}\left(1-m_{i, t}\right)=\prod_{t=a}^{A-1}\left(1-\xi_{i} m_{0, t}\right)
$$

Individual mortality factor $\xi_{i}$ can then be calculated as approximately:

$$
\xi_{i} \approx-\ln s_{i, a, A} / \sum_{t=a}^{A-1} m_{0, t}
$$

However, one shortcoming of this approach is that it does not allow calculating subjective annual mortality probabilities for persons who state that their subjective longevity probability is zero. It is not clear what the subjective survival probability for the next year should be for agents who don't expect to live for another 11 to 15 years. I employ two alternative approaches to this problem. One approach is to change the answer from $0 \%$ to $1 \%$ (similar to Khwaja, Sloan, and Chung. 2005). The other approach is to omit the observations with a subjective longevity probability of $0 \%$. I also test if estimation results change if observations with a subjective longevity expectation of $100 \%$ are excluded. The distribution of the subjective annual mortality rates and the life table annual mortality rates in the baseline estimation sample is shown in Figure 1. The mean subjective mortality rate is $3.6 \%$ as compared to $4.3 \%$ for life table mortality rates. The standard deviation for subjective mortality rates is $3.7 \%$, and it is $2.9 \%$ for life table mortality rates.

I use financial planning horizon as a proxy variable for time preferences. Specifically, I identify respondents with varying time preferences by the answer to the following question: "In deciding how much of their (family) income to spend or save, people are likely to think about different financial planning periods. In planning your saving and spending, which of the following time periods is most important to you?" Possible answers include the next few months, the next year, the next few years, the next 5-10 years and longer than 10 years. I divide the sample in three groups with financial planning horizon up to one year $(\mathrm{n}=130$, $35 \%$ of baseline sample), up to five years $(n=125,33.6 \%$ of sample), and longer $(n=116$, $31.4 \%$ of sample). This question was asked to all HRS respondents in wave 1, and to varying 
sub-samples of the HRS population in waves 4, and 5. I use the latest available answer and impute answers for some respondents who were never asked about their financial planning horizon. I use IVEware imputation and variance estimation software, which follows a sequential regression imputation method described in Ragunathan, Lepkowski, van Hoewyk, and Solenberger (2001). Table 2 shows descriptive statistics by financial planning horizon. The average growth rates of consumption vary widely from $-12 \%$ for persons with a short financial planning horizon to $3.4 \%$ for persons with a long financial planning horizon. This pattern agrees with prior expectations. All other things being equal, persons with lower time discount rate should experience faster consumption growth, and a longer financial planning horizon should correspond with lower time discount rates. Persons with a longer financial planning horizon are on average younger and face lower subjective mortality rates. They are also better educated, and have higher wealth and income.

I identify respondents with varying risk tolerance by the answer to the following question: "Your doctor recommends that you move because of allergies, and you have to choose between two possible jobs. The first would guarantee your current total family income for life. The second is possibly better paying, but the income is also less certain. There is a 5050 chance the second job would double your total lifetime income and a 50-50 chance that it would cut it by $20 \%$. Which job would you take - the first job or the second job?" Depending on the answer to this question, I divide the sample in two groups with high risk aversion $(\mathrm{n}=$ $254,68.4 \%$ of baseline sample), and with lower risk aversion ( $\mathrm{n}=127,31.6 \%$ of sample). This question was asked to the same samples as the question on financial planning horizon defined above. I use the latest available answer, and I impute some missing answers. Table 3 shows descriptive statistics by stated risk aversion. The average consumption growth rate is $1.8 \%$ for persons with low risk aversion and $-7.8 \%$ for persons with higher risk aversion. On average, more risk adverse persons also have higher incomes, while more risk tolerant persons have more assets, higher education, and are more likely to be male. 
Further variables employed in the analysis are total household income, which includes social security, employer pensions, and capital income, and total household net wealth, which includes net financial wealth, housing equity, the net value of businesses, and the value of vehicles. A binary variable whether or not the respondent is in good health is set to one if self reported overall health is excellent, very good, or good, and is set to zero if self reported health is fair or poor. The number of limitations in activities of daily living ranges from 0 to 6 , and represents whether respondents are able to independently walk, dress, bathe, eat, get into bed, and use the toilet.

\section{Identification Strategy}

My identification strategy follows directly from a standard life-cycle model. Consider a single retired agent who chooses consumption and saving in each period in order to maximize expected lifetime utility. I assume that utility is additively separable between periods, and that future utility is discounted with factor $\beta_{i}$, which can vary between agents. The subjective probability of survival from age $t$ to age $j$ is denoted as $s_{i, t, j}$ (with $j \geq t$ ). Then the maximization problem can be summarized as:

$$
\max E_{t} \sum_{j=t}^{T} \beta_{i}^{j-t} s_{i, t, j} u\left(c_{t}\right)
$$

where $T$ is the maximum age a person can live to, and $E_{t}$ is the expectations operator based on information in period $t$. I further assume that within-period-utility is given by a constant relative risk aversion (CRRA) utility function:

$$
u\left(c_{t}\right)=\frac{c_{t}^{1-\gamma_{i}}}{1-\gamma_{i}}
$$

where $\gamma_{i}$ is the parameter of relative risk aversion, which can vary between agents. The intertemporal elasticity of substitution is given by $1 / \gamma_{\mathrm{i}}$, the inverse of risk aversion. In each 
period agents receive income $\mathrm{y}_{\mathrm{t}}$ from Social Security and pensions. This income is nonstochastic. Social security payments increase with inflation (cost of living adjustment), and are constant in real terms. Agents face uncertain out of pocket medical expenditures $v_{t}$ in each period. Out of pocket medical expenditures are treated as exogenous and are not part of consumption. I assume that there is one asset that yields a risk free real return of $R_{t}$ between periods. Assets in period $t+1, a_{t+1}$, are determined by the following asset accumulation equation:

$$
a_{t+1}=R_{t}\left(a_{t}+y_{t}-c_{t}-v_{t}\right)
$$

Social Security entitlements cannot be used as collateral for loans and it is difficult to borrow against employer pensions. This credit constraint imposes the following restriction on consumption:

$$
c_{t} \leq a_{t}+y_{t}-v_{t}
$$

If the credit constraint is not binding, then the first order condition requires that the marginal utility from consumption in period $t$ is equal to the expected marginal utility from consumption expenditure in period $t+1$ :

$$
u^{\prime}\left(c_{t}\right)=R_{t} \beta_{i} s_{i, t, t+1} E_{t}\left[u^{\prime}\left(c_{t+1}\right)\right]
$$

Substituting the CRRA utility function into equation (3) yields:

$$
E_{t}\left[\left(\frac{c_{t+1}}{c_{t}}\right)^{\gamma_{i}}\right]=R_{t} \beta_{i} s_{i, t, t+1}
$$

Uncertainty about future consumption derives from stochastic out of pocket medical expenses. Under the assumption that consumption changes are log-normally distributed, equation (4) can be transformed into the following Euler equation:

$$
E_{t}\left(\Delta \ln c_{t+1}\right)=1 / \gamma_{i}\left(r_{t}-\delta_{i}-m_{i, t}\right)+\left(\gamma_{i} / 2\right) \operatorname{Var}_{t}\left(\Delta \ln c_{t+1}\right)
$$


where $\Delta \ln c_{t+1}=\ln c_{t+1}-\ln c_{t}$ is the growth rate of consumption, $r_{t}=\ln R_{t}$ is the real interest rate at time $t, \delta_{i}=-\ln \beta_{i}$ is the time discount rate for agent $\mathrm{i}$, and $m_{i, t}=-\ln s_{i, t, t+1}$, the subjective mortality rate of agent $i$ in period $t$. Equation (5) postulates that expected consumption growth should increase with higher real interest rates and decrease with higher time discount rates and higher mortality rates, and that these effects should be smaller for more risk averse agents. Expected consumption growth should increase with a higher variance of consumption growth. An Euler equation very similar to equation (5) can also be derived without the assumption of log-normally distributed consumption growth rates from a $2^{\text {nd }}$ order Taylor approximation of equation (4) (Carroll 2001, Ludvigson and Paxson 2001).

The empirical model follows closely from equation (5). I estimate the following least squares regression:

$$
\Delta \ln c_{i, t+1}=a_{0}+a_{1} m_{i, t}+a_{2} h_{i, t}+\varepsilon_{i, t}
$$

where $a_{0}, a_{1}$, and $a_{2}$ are regression coefficients, $m_{i, t}$ is the subjective annual mortality rate, and $h_{i, t}$ is the variance of out of pocket medical expenditures for agent $i$ at time $t . \varepsilon_{i, t}$ is an error term, which reflects health cost shocks and measurement errors of consumption growth. Consumption growth is expected to be lower for agents with higher subjective mortality rates, because such agents are expected to consume more now and less in future periods. Consumption growth is expected to be higher for individuals with a higher variance of expected future out-of-pocket medical expenditures, because such agents have a stronger precautionary savings motive.

Utility parameters $\gamma$ and $\delta$ can be calculated from the coefficients in regression equation (6). The estimated relative risk aversion parameter can be computed as

$$
\gamma=-1 / a_{1}
$$


I estimate relative risk aversion parameters, separately for the full sample and for subsamples, to which respondents are assigned according to their answer to a survey question about the willingness to accept lifetime income gambles. This approach allows examining, whether and how much relative risk aversion varies across agents.

If the real interest rate $r_{t}$ is known, then the time discount rate can be derived from:

$$
\delta=a_{0} / a_{1}+r_{t}
$$

I examine how time discount rates vary with the answer to a survey question on financial planning horizon. Financial planning horizon stands as a proxy variable for the time discount rate, which cannot be directly observed. I expect that agents with longer financial planning horizons also have lower time discount rates.

I calculate the individual-specific risk of health costs based on out of pocket medical expenditures of HRS respondents in the two years preceding the 2002 interview. Out of pocket expenditures, oop $_{i, t}$, include hospital costs, nursing home costs, doctor visit costs, dentist costs, outpatient surgery costs, average monthly prescription drug costs, home health care, and the cost of special facilities. I calculate the variance of out of pocket medical expenditures by the following two stage procedure. The first stage regression equation is:

$$
\mathrm{oop}_{i, t+1}=b_{0}+b_{1} x_{i, t}+\eta_{i, t}
$$

where $x_{i, t}$ is a vector of covariates from the 2000 HRS survey. Covariates include out of pocket medical expenditures in previous waves, information on health insurance, age, years of education, gender, self reported health of good or better, total financial wealth, and total household income, the number of limitations in activities of daily living, and previous diagnoses of diabetes, cancer, lung diseases, heart diseases, stroke, and psychological disorders. The second stage estimation regresses the squared error term of the first stage regression on the same covariates as above: 
$\hat{\eta}_{i, t}^{2}=c_{0}+c_{1} x_{i, t}+\mu_{i, t}$

The estimated variance of medical expenditure, $\hat{h}_{i, t}$, is then computed by:

$\hat{h}_{i, t}=\hat{c}_{0}+\hat{c}_{1} x_{i, t}$

This approach allows identifying agents with varying risk of medical expenditures. $\hat{\mathrm{h}}_{\mathrm{i}, \mathrm{t}}$ is included in regression equation (6) as a proxy for overall consumption risk.

However, there are several caveats in interpreting the results from regression equation (6). The first caveat concerns the validity of Euler equation estimates in the presence of credit constrained agents and buffer-stock savers. If the credit constraint in equation (2) binds, then the first order condition in equation (3) might not hold with equality, and utility parameters estimated from regression equation (6) are inconsistent. Carroll $(1998,2001)$ points out that a similar argument can also hold for households with positive wealth who are buffer-stock savers. Buffer-stock savers have only a precautionary savings motive. In the absence of consumption uncertainty they would borrow against future income. In a simplified description, buffer-stock savers always hold a certain target wealth as insurance against negative shocks and never exceed their target wealth. The consumption growth of bufferstock savers is not affected by changing mortality rates, which implies that in the presence of buffer-stock savers utility parameters estimated from equation (6) can be inconsistent. However, this is less of a concern for the elderly than for younger agents. Buffer stock savers are more likely to be individuals with a low wealth to income ratio and high income growth. In contrast, retirees tend to hold sizeable wealth in relation to their incomes, and the real income of retirees is often stable. I identify constrained agents using the answer to the following survey question about spending intentions of a windfall gain: "Suppose next year you were to find your household with $20 \%$ more income than normal, what would you do with the extra income?" For the estimation of utility parameters I exclude all agents from the 
sample, who answer that they would spend the entire windfall gain. This leaves a sample of agents who are not credit constrained or buffer-stock savers.

A second caveat concerns the validity of the financial planning horizon as proxy variable for the time discount rate. While it is plausible that agents with a lower time discount rate have a longer financial planning horizon, this is also likely to be true for people with higher wealth, income, or better health (Khwaja, Sloan, and Salm 2006). These factors are also determinants of subjective mortality rates. This could lead to biased estimates of time discount rates. In order to evaluate this potential problem I test, whether the estimation results are sensitive to the inclusion of additional variables for wealth, income, and health.

Also, the variance of out of pocket medical expenditures is not a perfect proxy for consumption risk. The consumption of agents with little liquid wealth is likely to vary more with out of pocket medical expenditures than the consumption of agents with high financial wealth. Therefore, I estimate the effect of out of pocket medical cost variance separately for households with financial wealth above and below the median in my sample, and I examine if the coefficient estimates are sensitive to this change.

A further caveat concerns the effect of ill health on consumption. The utility derived from consumption could depend on agents' health (Viscusi and Evans 1990). Both consumption capacities and needs are likely to be affected by ill health, while the risk of deteriorating health might increase with higher mortality rates. As a test for potential bias, I examine if consumption growth is linked to changes in the ability to perform activities of daily living (ADL's), and whether estimation results are sensitive to the inclusion of a variable that represents changes in ADL's.

The identification strategy discussed above does not explicitly account for a bequest motive. However, a bequest motive would affect the levels of consumption in all periods, but 
not necessarily the changes in consumption. Since this study examines changes in consumption, the identification strategy can still be valid in the presence of a bequest motive.

\section{Results}

\section{A. Estimating the variance of out of pocket medical expenses}

The variance of out of pocket medical expenditures is estimated in two stages, as described in the previous section. The first column of Table 4 shows the first stage regression results. Out of pocket medical expenditures in the two years before the year 2002 interview increase with previous out of pocket medical expenditures in the two years before the year 2000 interview by $\$ 0.40$ for every dollar of previous expenditures. They also increase with age (by $\$ 72$ every year) and education level (by $\$ 155$ for every additional year of schooling), and are lower for men (by \$384) and for people whose self-reported health is good or better (by $\$ 621$ ). All explanatory variables refer to the year 2000. Medical expenses are higher for agents with private health insurance (by \$837) and lower for agents who receive Medicaid (by \$2,045). Medical expenses for agents with employer health insurance and no health insurance are not significantly different from agents who are covered by Medicare only, which is the omitted health insurance category. Medical expenses also increase with a higher number of limitations in activities of daily living (by $\$ 701$ for every additional limitation), and with previous diagnoses of cancer, heart diseases and stroke. There are no statistically significant effects of income, financial wealth, and previous diagnoses of diabetes, lung diseases, and psychological disorders. The second column of Table 4 shows the second stage estimation results with the squared residuals of the first stage regression as dependent variable. The dependent variable is scaled down by a factor $1,000,000$. The variance of out of pocket medical expenditures increases with higher previous out of pocket medical expenditures. It is lower for individuals, whose self reported health is good or better. In order to increase 
efficiency, the variance of out of pocket medical expenditures is estimated based on the entire available HRS sample, which includes 17,095 observations. As an informal test of whether health cost risk as defined above is a good proxy for the variance of consumption growth, I calculated the correlation between health cost risk and the square of the deviation from the mean of consumption growth. For the baseline sample, the correlation coefficient is 0.086 , which is significantly different from zero at the ten percent level.

\section{B. Baseline regression, spending intentions, food consumption}

Table 5 shows estimation results for Euler equations as specified in the empirical model in equation (6). The estimation sample includes all persons, who participated in both waves of the Consumption and Activities Mail Survey, and who were age 65 or older and lived in a single person household at the time of the year 2000 HRS interview. Persons with subjective longevity probabilities of zero are excluded from the sample (They are included in the estimation in column 4 of Table 6). The baseline regression in column 1 also excludes individuals from the sample who intend to immediately spend a windfall gain. The remaining sample includes 371 observations. The dependent variable is the growth rate of real annual consumption expenditures on nondurable goods. Consumption growth decreases with higher subjective mortality rates; an increase in the subjective mortality rate by $1 \%$ is associated with a consumption decline of $1.98 \%$ per annum. This is consistent with consumption behavior predicted by the lifecycle model. Consumption growth also increases with the variance of out of pocket medical expenditures, which provides evidence for a precautionary savings motive.

Column 2 shows estimation results for the same regression specification as in column 1 , but the sample is now restricted to 47 respondents who intend to immediately spend a windfall gain. As discussed above, consumption growth of credit constrained consumers and of buffer-stock savers should not depend on subjective mortality rates and time preferences. 
Indeed, I find none of the estimation coefficients is significantly different from zero. The effect of a $1 \%$ increase of the subjective mortality rate on consumption growth is now an increase of $0.19 \%$ per annum as opposed to a decline of $1.98 \%$ of for non-constrained agents in column 1. This result indicates that stated spending intentions from a survey question can identify credit constrained consumers and buffer-stock savers. The results also lend support to Carroll's (2001) warning not to estimate utility parameters from Euler equations without controlling for buffer-stock saving. Column 3 repeats this estimation for a combined sample that includes both constrained and unconstrained consumers. The coefficients for subjective mortality rates and health cost risk are significant, and results are similar to the baseline regression in column (1). A $1 \%$ increase in the subjective mortality rate is now associated with a decline of $1.72 \%$ in consumption growth.

Column 4 of Table 5 replicates the baseline estimation for a different measure of consumption growth, the percentage change of at home food consumption. Due to a lack of better data, previous studies have often resorted to food consumption as a proxy for total household consumption (Browning and Lusardi 1996). The effect of subjective mortality rates on at home food consumption growth is slightly negative at -.09 , but not significantly different from zero, as opposed to -1.98 in the baseline regression. This result adds further evidence to the argument that food consumption is not additively separable from other nondurable consumption goods, and is therefore not a good proxy for nondurable consumption.

\section{Alternative specifications of mortality expectations}

Table 6 shows estimation results for various alternative specifications of subjective mortality rates. Column 1 includes life table mortality rates instead of subjective mortality rates. The point estimate of the coefficient for life table mortality rates is -1.91 , which is close 
to the coefficient for subjective mortality rates in the baseline regression. However, due to a higher standard error the coefficient is now significantly different from zero only at the ten percent level. The estimation coefficient of health cost risk is similar to the baseline regression. The $\mathrm{R}^{2}$ of 0.026 in the estimation based on life table mortality rates is also somewhat lower than the $\mathrm{R}^{2}$ of 0.035 based on subjective mortality rates. This result is in accordance with the finding in Gan, Gong, Hurd, and McFadden (2004) that the explanatory power of subjective mortality rates on intertemporal consumption choice is higher than for life table mortality rates.

Column 2 of Table 6 replaces the mortality rate with the individual specific mortality factor, which measure deviations between life table mortality rates and subjective mortality expectations. I find that a higher individual mortality factor has a significant negative impact on consumption growth. This result shows that the effect of subjective mortality rates on consumption growth is not just driven by cohort effects.

Column 3 excludes 37 observations with subjective longevity expectations of $100 \%$ from the sample. This permits testing whether the estimation results are driven by focal values. The result shows that estimation results are in essence unchanged after the exclusion of focal answers. Column 4 includes 53 observations with a subjective longevity expectation of zero. As discussed in section 3, subjective annual mortality rates cannot be easily calculated for respondents with a zero longevity expectations. So far, I excluded these observations from the sample. In column 4, I assume that respondents who stated their subjective longevity probability as zero have in fact a subjective longevity probability of 0.01 , which allows me to calculate subjective annual mortality rates. The estimated coefficient of the subjective mortality rate on consumption growth now declines from -1.98 in the baseline regression to -0.85 , which is still significantly different from zero at the $5 \%$ level. Several possible explanations could account for the change in the estimation results. First, focal 
answers might not reflect respondents' actual expectations. The average calculated annual subjective mortality rate for agents who report a zero longevity probability is $20.7 \%$ compared to $3.6 \%$ for the baseline sample. Actual mortality expectations of focal respondents might be lower. Another possible explanation is that respondents who give focal answers to survey questions differ in their risk aversion and consumption and saving behavior from other agents, which could explain different estimation results.

\section{Heterogeneous time and risk preferences}

Table 7 shows regression results for alternative levels of stated preferences, which allows calculating relative risk aversion and time discount rates separately for agents with different levels of stated risk aversion and different financial planning horizons. The regression specification in column 1 is the same as for the baseline regression. However, the sample is restricted to the 254 respondents whose response to a survey question about the willingness to accept an income gamble points towards low risk tolerance (that is high risk aversion). The coefficient of the subjective mortality rate of -1.34 is smaller than in the baseline regression in absolute value terms. The lifecycle model predicts that the effect of subjective mortality rates on lower consumption growth should be smaller for more risk adverse agents.

The regression specification in column 2 of Table 7 is as before, but the sample is now comprised of 117 respondents whose answers to the income gamble question point towards higher than average risk tolerance (that implies low risk aversion). As the theory predicts, the coefficient of subjective mortality rate of -3.32 is now higher than in the baseline regression. The estimation shown in column 3 is based on the same sample as the baseline regression, but includes two additional binary variables, which take the value of one for respondents, whose financial planning horizon is either between 1 and 5 years or greater than five years. As 
compared to the omitted reference group that includes respondents with a financial planning horizon of one year or less, the average consumption growth rate increases by $3.3 \%$ for agents with a medium planning horizon, and by $13.3 \%$ for agents with a long financial planning horizon. Theory implies that consumption growth is higher for agents with lower time discount rates. My results indicate that respondents who report longer financial planning horizons in survey questions have lower time discount factors, and also that the time discount rates vary substantially between persons.

\section{E. Sensitivity analysis}

The estimation shown in column 1 of Table 8 is identical to column 3 of Table 7 except for the inclusion of additional explanatory variables for income, total assets, good health, and changes in ADL limitations. As discussed in section 3, I am concerned that financial planning horizon, which I use as a proxy for time discount rates, is also related to determinants of longevity, such as income, wealth, and health. Therefore, I test whether the estimation coefficients are sensitive to the inclusion of these variables. I also test if consumption growth is dependent on changes in ADL limitations. The results show that none of the additional variable coefficients are significantly different from zero, and that the estimated coefficients for subjective mortality rates, financial planning horizon and health cost risk do not change.

In column 2 of Table 8 , the effect of health cost risk on consumption growth is estimated separately for agents with financial wealth below the median in the sample and above the median in the sample. Theory predicts that health cost risk should have a stronger impact on the consumption variance of people with low financial wealth than for people with high financial wealth, because financial wealth provides a cushion against negative health cost shocks. I find indeed that health cost risk has a stronger impact on consumption growth for 
individuals with below median wealth than for people with above median wealth. The estimation coefficient of subjective mortality rates is almost unchanged compared to the baseline estimation.

\section{F. Estimated time discount rates and relative risk aversion parameters}

The final step in my analysis is to calculate utility parameters of time discount rates and relative risk aversion parameters from the regression results in tables 5 and 7 . Based on the regression coefficients relative risk aversion parameters can be calculated according to equation 7 , and time discount factors according to equation 8 . Both equations are discussed in section 3. For calculating time discount rates separately by financial planning horizon, I add the coefficient of the relevant financial planning horizon category to the constant. Average relative risk aversion calculated from the baseline regression (Table 5, column 1) is 0.50 . The inter-quartile range of the relative risk aversion parameter, which I calculated using a bootstrap with 200 repetitions, ranges from 0.40 to 0.65 . Risk aversion in the sample with high stated risk aversion (Table 7 , column 1) is 0.74 , and in the sample with low stated risk aversion (Table 7, column 2) it is 0.30 . Time discount rates can be calculated if the real interest is known. I assume a real interest rate of $3 \%$, which corresponds to a long run average of real interest rates for long term U.S. government bonds. Then the average time discount rate (calculated from Table 5, column 1) is 0.043 , with an inter-quartile range from 0.031 to

0.061. For agents with a short financial planning horizon the time discount rate is given by 0.079, as compared to 0.060 for agents with medium financial planning horizon and 0.003 for agents with high a long financial planning horizon. The estimates of time discount rates and relative risk aversion parameters are also shown in Table 9.

How do these parameter estimates compare to the previous literature? The only study known to the author that uses subjective mortality rates to estimate utility parameters is Gan, 
Gong, Hurd, and McFadden. (2004). They estimate a relative risk aversion parameter of 0.98, which is closest to my estimate for the most risk averse group, and a time discount rate of 0.058, which is close to my estimate for the group with a medium financial planning horizon. Other studies that estimate relative risk aversion parameters from life table mortality rates tend to estimate higher values of relative risk aversion, that range from 1.08 (Hurd 1989), to 2.1 (Skinner 1985), 3 (Palumbo 1999), to 8.2 (De Nardi, French, and Jones 2005).

\section{Conclusion}

In summary, I find that information about subjective mortality rates, and time and risk preferences elicited from survey questions can help to better understand the saving and consumption behavior of the elderly. The main findings are: First, consumption growth decreases with higher subjective mortality rates, which is consistent with the predictions of the lifecycle model. Second, estimated utility parameters vary with answers to survey questions about the respondents' financial planning horizon and willingness to accept income gambles, which indicates that answers to survey questions can contain meaningful information about time and risk preferences. Third, I find substantial variation in estimated in estimated risk aversion parameters and time discount rates. Relative risk aversion is estimated to be two and a half times higher (0.74 as compared to 0.3$)$ for agents with high stated risk aversion than for agents with low stated risk aversion. Estimated time discount rates vary from $0.3 \%$ for agents with the longest financial planning horizon to $7.9 \%$ for agents with the shortest financial planning horizons. These results indicate that heterogeneous preferences play a role in explaining the consumption and saving behaviors of the elderly.

There are many questions open for future research. One topic for future research could be to quantify the effects of heterogeneous preferences on wealth holdings and on explaining differences in wealth levels. Another topic could be to expand the analysis to married couples 
and to examine the effect of mortality expectations of both spouses on intertemporal consumption choices of couple households.

\section{References}

Aguiar, M. and E. Hurst (2005), "Conumption versus expenditure", Journal of Political Economy, 113 (5), 919-948.

Attanasio, O., and H. Hoynes (2000), "Differential mortality and wealth accumulation," Journal of Human Resources, 35 (1), 1 -29.

Attanasio, O. and G. Weber (1995), "Is consumption growth consistent with intertemporal optimization? Evidence for the Consumer Expenditure Survey," Journal of Political Economy, 103 (6), 1121 - 1157.

Barsky, R., F. Juster, M. Kinball, M. Shapiro (1997), "Preference parameters and behavioral heterogeneity: An experimental approach in the health and retirement study," Quarterly Journal of Economics, 112 (2), 537 - 579.

Bernheim, B., J. Skinner, and S. Weinberg (2001), "What accounts for the variation in retirement wealth among U.S. households?" American Economic Review, 91 (4), 832 -857.

Bernheim, B. (2002), "Taxation and Saving", Chapter 18 in Handbook of Public Economics, edited by A. Auerbach and M. Feldstein, Elsevier.

Bloom, D., D. Canning, and B. Graham (2003), "Longevity and Life-cycle Savings," Scandinavian Journal of Economics, 105 (3), 319 - 338.

Butrica, B., J. Goldwyn, and R. Johnson (2005), "Understanding expenditure patterns in retirement," Working Paper, Urban Institute.

Caroll, C. (1998), "Buffer-stock Saving and the Life Cycle/ Permanent Income Hypothesis," Quarterly Journal of Economics, 112 (1), 1 - 55.

Caroll, C. (2001), "Death to the log-linearized consumption Euler equation! (and very poor health to the second order approximation)," Working Paper.

DeNardi, M., E. French, and J. Jones (2005), "Sex, Income shocks, and the savings of elderly singles," Working Paper.

Dynan, K., J. Skinner, and S. Zeldes (2002), "The importance of bequests and lifecycle saving in capital accumulation: A new answer," American Economic Review, 92 (2), $274-278$.

Dynan, K., J. Skinner, and S. Zeldez (2004), "Do the rich save more?" Journal of Political Economy, 112 (2), 397 - 444.

Gan, L. M. Hurd, and D. McFadden (2003), "Individual subjective survival curves," NBER Working Paper 9480.

Gan, L., G. Gong, M. Hurd, and D. McFadden (2004), "Subjective mortality risk and bequest," NBER Working Paper 10789.

Hamermesh, D. (1985), "Expectations, Life Expectancy, and Economic Behavior," Quarterly Journal of Economics, 50 (2), 389 - 408. 
Harrison, G., M. Lau, and M. Williams (2002), "Estimating individual discount rates in Denmark: A field experiment”, American Economic Review, 92 (5), 1606 - 1617.

Hurd, M. (1987), "Savings of the elderly and desired bequests," American Economic Review, 77 (3), 298 - 312.

Hurd, M. (1989), “Mortality risk and bequests,” Econometrica, 57 (4), 779 -813.

Hurd, M. (1990), "Research on the elderly: Economic status, retirement, and consumption and saving," Journal of Economic Literature, 28 (2), 565 - 637.

Hurd, M. and K. McGarry (1995), "Evaluations of the Subjective Probabilities of Survival in the Health and retirement Study," Journal of Human resources, 30, Supplement, S268 - S292.

Hurd, M., and K. McGarry (2002), "The Predictive Validity of Subjective Probabities of Survival," Economic Journal, 112, 966 - 985.

Kapteyn, A. and F. Teppa (2003), "Hypothetical intertemporal consumption choices," Economics Journal, 113, 140 - 152.

Khwaja, A., F. Sloan, and S. Chung (2005), “Expectations' errors and individual behaviors: Evidence on the relationship between mortality expectations and individual behaviors," Working Paper.

Khwaja, A., Sloan, F., and M. Salm (2006), "Preferences and subjective beliefs of risk takers: The case of smokers," International Journal of Industrial Organization, 24 (4), 667682.

Ludvigson, S. and C.Paxson (2001), "Approximation bias in linearized Euler equations," Review of Economics and Statistics, 83 (2), 242-256.

Lusardi, A., and M. Browning (1996), "Household Saving: Micro theories and micro facts," Journal of Economic Literature, 34 (4), 1797 - 1855.

Manski, C. (2004), “Measuring Expectations," Econometrica, 72 (5), 1329 - 1376.

Modigliani, F. and R. Brumberg (1954), "Utility analysis and the consumption function: An interpretation of the Cross- Section data," in: Post Keynesian Economics, edited by K. Kurihara, Rutgers University Press.

Palumbo, M. G. (1999), "Uncertain medical expenses and precautionary saving near the end of the life-cycle," Review of Economic Studies, 66 (2), 395 - 421.

Parker, J., and B. Preston (2005), "Precautionary saving and consumption fluctuations," American Economic Review, 95 (4), 1119 - 1143.

Ragunathan, Lepkowski, Van Hoewyk, and Solenberger (2001), "A multivariate technique for multiply imputing missing values using a sequence of regression models," Survey Methodology, June 2001

Skinner, J. (1985), "Variable lifespan and the intertemporal elasticity of consumption," Review of Economics and Statistics, 67 (4), 616 - 623.

Smith, V. K., D. Taylor, and F. Sloan (2001), "Longevity expectations and death: Can people predict their own demise?" American Economic Review, 91 (4), 1126 - 1134.

Yaari, M. (1965), "Uncertain lifetime, life insurance, and the theory of the consumer," Review of Economic Studies, 32, 137 -150. 
Table 1: Descriptive statistics

\begin{tabular}{|c|c|c|}
\hline & Mean & Std. Dev. \\
\hline \multicolumn{3}{|l|}{ Estimating consumption growth } \\
\hline Consumption growth & -0.059 & 0.502 \\
\hline Food consumption growth $(\mathrm{N}=336)$ & 0.034 & 0.511 \\
\hline Subjective mortality & 0.036 & 0.037 \\
\hline Pessimism factor & 1.041 & 1.029 \\
\hline Life table mortality & 0.043 & 0.029 \\
\hline Health cost risk (in $1,000,000$ ) & 180.237 & 314.887 \\
\hline Age & 75.264 & 6.489 \\
\hline Male & 0.196 & 0.398 \\
\hline Years of education & 12.409 & 2.783 \\
\hline Income (in $\$ 1,000$ ) & 29.259 & 38.443 \\
\hline Total assets (in $\$ 1.000$ ) & 248.002 & 332.136 \\
\hline Good health & 2.541 & 1.034 \\
\hline ADL change & 0.037 & 0.591 \\
\hline Low risk aversion & 0.319 & 0.466 \\
\hline High risk averion & 0.681 & 0.466 \\
\hline Short financial planning horizon & 0.351 & 0.477 \\
\hline Medium financial planning horizon & 0.336 & 0.473 \\
\hline Long financial planning horizon & 0.312 & 0.464 \\
\hline Intention spend all $(\mathrm{N}=418)$ & 0.112 & 0.316 \\
\hline $\begin{array}{l}\text { Number of observations } \\
\text { (baseline estimation) }\end{array}$ & 371 & \\
\hline \multicolumn{3}{|l|}{ Estimating health cost risk } \\
\hline Out of pocket payment (in \$) & $3,788.81$ & $15,012.62$ \\
\hline Previous Out of pocket payment (in \$) & $2,264.35$ & $6,040.85$ \\
\hline Age & 67.387 & 10.454 \\
\hline Years of education & 12.129 & 3.335 \\
\hline Male & 0.408 & 0.491 \\
\hline Good health & 0.744 & 0.435 \\
\hline Employer health insurance & 0.543 & 0.498 \\
\hline Private health insurance & 0.183 & 0.387 \\
\hline Medicaid & 0.082 & 0.275 \\
\hline No health insurance & 0.050 & 0.219 \\
\hline Financial wealth (in $\$ 1,000$ ) & 113.673 & 437.104 \\
\hline Income (in $\$ 1,000$ ) & 54.375 & 104.496 \\
\hline ADL limitations & 0.298 & 0.857 \\
\hline Diabetes & 0.145 & 0.352 \\
\hline Cancer & 0.111 & 0.314 \\
\hline Lung disease & 0.079 & 0.269 \\
\hline Heart disease & 0.217 & 0.412 \\
\hline Stroke & 0.069 & 0.254 \\
\hline Psychological disorder & 0.133 & 0.340 \\
\hline Number of observations & 17095 & \\
\hline
\end{tabular}


Table 2: Descriptive statistics by financial planning horizon

\begin{tabular}{lccc}
\hline & $\begin{array}{c}\text { Short financial } \\
\text { planning horizon } \\
(\mathrm{N}=130)\end{array}$ & $\begin{array}{c}\text { Medium financial } \\
\text { planning horizon } \\
(\mathrm{N}=125)\end{array}$ & $\begin{array}{c}\text { Long financial } \\
\text { planning horizon } \\
(\mathrm{N}=116)\end{array}$ \\
\hline Consumption growth & -0.120 & -0.084 & 0.034 \\
Subjective mortality & $(0.509)$ & $(0.562)$ & $(0.407)$ \\
& 0.041 & 0.039 & 0.028 \\
Age & $(0.038)$ & $(0.039)$ & $(0.031)$ \\
Male & 76.376 & 75.520 & 73.741 \\
& $(6.799)$ & $(6.483)$ & $(5.871)$ \\
Years of education & 0.215 & 0.144 & 0.232 \\
Income (in \$1,000) & $(0.412)$ & $(0.352)$ & $(0.424)$ \\
Total Assets (in \$ 1,000) & 12.007 & 12.424 & 12.844 \\
& $(2.889)$ & $(3.022)$ & $(2.309)$ \\
Good health & 24.769 & 25.000 & 38.800 \\
& $(23.813)$ & $(24.275)$ & $(57.858)$ \\
& 206.643 & 227.072 & 316.908 \\
& $(274.937)$ & $(304.220)$ & $(403.904)$ \\
\end{tabular}

Table 3: Descriptive statistics by risk aversion based on income gamble question

\begin{tabular}{lcc}
\hline & $\begin{array}{c}\text { Low risk aversion } \\
(\mathrm{N}=117)\end{array}$ & $\begin{array}{c}\text { High risk aversion } \\
(\mathrm{N}=254)\end{array}$ \\
\hline Consumption growth & -0.018 & -0.078 \\
& $(0.573)$ & $(0.465)$ \\
Subjective mortality & 0.033 & 0.038 \\
& $(0.033)$ & $(0.038)$ \\
Age & 75.658 & 75.082 \\
& $(6.122)$ & $(6.655)$ \\
Male & 0.230 & 0.181 \\
& $(0.423)$ & $(0.385)$ \\
Years of education & 12.760 & 12.248 \\
& $(2.683)$ & $(2.818)$ \\
Income (in $\$ 1,000)$ & 27.053 & 30.275 \\
Total Assets (in $\$ 1,000)$ & $(26.229)$ & $(42.926)$ \\
Good health & 281.287 & 232.671 \\
& $(346.386)$ & $(324.913)$ \\
& 0.823 & 0.811 \\
& $(0.382)$ & $(0.382)$ \\
\hline
\end{tabular}




\section{Table 4: Variance of out of pocket medical expenditure}

\begin{tabular}{|c|c|c|}
\hline & $\begin{array}{l}\text { Out of pocket } \\
\text { payments } \\
\text { (1) }\end{array}$ & $\begin{array}{c}\text { Squared } 1^{\text {st }} \text { stage } \\
\text { error } \\
\text { (2) }\end{array}$ \\
\hline Previous out of pocket payment & $\begin{array}{l}0.403^{\star * *} \\
(0.019)\end{array}$ & $\begin{array}{c}0.04^{\star \star \star} \\
(0.015)\end{array}$ \\
\hline Age & $\begin{array}{l}72.773^{\star \star \star} \\
(12.816)\end{array}$ & $\begin{array}{l}-1.949 \\
(9.973)\end{array}$ \\
\hline Years of education & $\begin{array}{l}155.614^{* \star *} \\
(38.595)\end{array}$ & $\begin{array}{c}48.791 \\
(30.035)\end{array}$ \\
\hline Male & $\begin{array}{l}-384.05^{\star} \\
(232.765)\end{array}$ & $\begin{array}{c}118.989 \\
(181.137)\end{array}$ \\
\hline Good health & $\begin{array}{l}-621.619^{\star \star} \\
(302.624)\end{array}$ & $\begin{array}{l}-489.988^{\star \star} \\
(235.501)\end{array}$ \\
\hline Employer health insurance & $\begin{array}{c}-74.869 \\
(318.152)\end{array}$ & $\begin{array}{c}78.092 \\
(247.585)\end{array}$ \\
\hline Private health insurance & $\begin{array}{l}837.454^{* *} \\
(353.474)\end{array}$ & $\begin{array}{c}78.192 \\
(275.072)\end{array}$ \\
\hline Medicaid & $\begin{array}{r}-2,045.64^{* * *} \\
(466.492)\end{array}$ & $\begin{array}{c}22.82 \\
(363.023)\end{array}$ \\
\hline No health insurance & $\begin{array}{c}544.093 \\
(583.747)\end{array}$ & $\begin{array}{c}34.661 \\
(454.270)\end{array}$ \\
\hline Financial wealth (in $\$ 1000$ ) & $\begin{array}{c}0.388 \\
(0.310)\end{array}$ & $\begin{array}{c}0.033 \\
(0.024)\end{array}$ \\
\hline Income (in \$1000) & $\begin{array}{l}-0.467 \\
(1.333)\end{array}$ & $\begin{array}{l}-0.867 \\
(1.037)\end{array}$ \\
\hline ADL limitations & $\begin{array}{l}812.358^{* * *} \\
(148.767)\end{array}$ & $\begin{array}{c}-51.153 \\
(115.770)\end{array}$ \\
\hline Diabetes & $\begin{array}{c}439.465 \\
(329.110)\end{array}$ & $\begin{array}{l}-144.19 \\
(256.113)\end{array}$ \\
\hline Cancer & $\begin{array}{l}742.387^{* *} \\
(361.264)\end{array}$ & $\begin{array}{c}-67.372 \\
(281.135)\end{array}$ \\
\hline Lung disease & $\begin{array}{l}-413.817 \\
(426.789)\end{array}$ & $\begin{array}{l}-289.935 \\
(332.126)\end{array}$ \\
\hline Heart disease & $\begin{array}{l}648.529 * * \\
(290.909)\end{array}$ & $\begin{array}{c}325.766 \\
(226.385)\end{array}$ \\
\hline Stroke & $\begin{array}{c}1,547.69^{\star \star *} \\
(464.668)\end{array}$ & $\begin{array}{c}253.784 \\
(361.603)\end{array}$ \\
\hline Psychological disorder & $\begin{array}{c}288.257 \\
(346.609)\end{array}$ & $\begin{array}{l}-177.488 \\
(269.730)\end{array}$ \\
\hline Observations & 17095 & 17095 \\
\hline R-squared & 0.05 & 0.001 \\
\hline
\end{tabular}

Huber- White standard errors in brackets

${ }^{*}$ significant at $10 \%$; ${ }^{* *}$ significant at $5 \%$; ${ }^{* * *}$ significant at $1 \%$ 
Table 5: Baseline regression, spending intentions, and food consumption

\begin{tabular}{lcccc}
\hline & $\begin{array}{c}\text { Consumption } \\
\text { Change } \\
\text { Not spend all } \\
(1)\end{array}$ & $\begin{array}{c}\text { Consumption } \\
\text { Change } \\
\text { Spend all } \\
(2)\end{array}$ & $\begin{array}{c}\text { Consumption } \\
\text { Change } \\
\text { Both samples }\end{array}$ & $\begin{array}{c}\text { Food } \\
\text { Consumption } \\
\text { Change } \\
(3)\end{array}$ \\
\hline Subjective mortality & $-1.986^{* * *}$ & 0.195 & $-1.729^{* * *}$ & -0.091 \\
& $(0.701)$ & $(1.379)$ & $(0.652)$ & $(0.835)$ \\
Health cost risk & $0.0002^{* *}$ & -0.0001 & $0.0002^{* *}$ & $0.0002^{*}$ \\
Observations & $(0.0001)$ & $(0.0001)$ & $(0.0001)$ & $(0.0001)$ \\
R-squared & 371 & 47 & 418 & 336 \\
\hline
\end{tabular}

Huber-White standard errors in brackets

${ }^{*}$ significant at $10 \%$; ${ }^{* *}$ significant at $5 \% ;{ }^{* * *}$ significant at $1 \%$

Table 6: Alternative specifications of mortality expectations

\begin{tabular}{|c|c|c|c|c|}
\hline & $\begin{array}{c}\text { Consumption } \\
\text { Growth } \\
\text { (1) }\end{array}$ & $\begin{array}{c}\text { Consumption } \\
\text { Growth } \\
\text { (2) }\end{array}$ & $\begin{array}{l}\text { Consumption } \\
\text { growth } \\
\text { (no 100\% } \\
\text { answer) } \\
(3)\end{array}$ & $\begin{array}{l}\text { Consumption } \\
\text { growth } \\
\text { (with 0\% } \\
\text { answer) } \\
\text { (4) }\end{array}$ \\
\hline Subjective mortality & & & $\begin{array}{l}-1.857^{\star \star} \\
{[0.742]}\end{array}$ & $\begin{array}{l}-0.854^{*} \\
{[0.444]}\end{array}$ \\
\hline Life table mortality & $\begin{array}{l}-1.917^{\star} \\
{[1.997]}\end{array}$ & & & \\
\hline Pessimism factor & & $\begin{array}{l}-0.043^{*} \\
{[0.024]}\end{array}$ & & \\
\hline Health cost risk & $\begin{array}{l}0.0002^{* *} \\
{[0.0001]}\end{array}$ & $\begin{array}{l}0.0002^{* *} \\
{[0.0001]}\end{array}$ & $\begin{array}{l}0.0002^{*} \\
{[0.0001]}\end{array}$ & $\begin{array}{l}0.0002^{* *} \\
{[0.0001]}\end{array}$ \\
\hline Observations & 371 & 371 & 326 & 424 \\
\hline R-squared & 0.03 & 0.02 & 0.03 & 0.02 \\
\hline
\end{tabular}

Huber-White standard errors in brackets

${ }^{*}$ significant at $10 \% ;{ }^{* *}$ significant at $5 \% ;{ }^{* * *}$ significant at $1 \%$ 
Table 7: Heterogeneous time and risk preferences

\begin{tabular}{lccc}
\hline & $\begin{array}{c}\text { Consumption } \\
\text { growth } \\
\text { (high risk } \\
\text { aversion) }\end{array}$ & $\begin{array}{c}\text { Consumption } \\
\text { growth } \\
\text { (low risk } \\
\text { aversion) }\end{array}$ & $\begin{array}{c}\text { Consumption } \\
\text { Growth }\end{array}$ \\
& $(1)$ & $(2)$ & $(3)$ \\
\hline Subjective mortality & $-1.348^{*}$ & $-3.328^{* *}$ & $-1.767^{* *}$ \\
Health cost risk & {$[0.788]$} & {$[1.442]$} & {$[0.700]$} \\
& 0.0001 & 0.0003 & 0.0002 \\
Medium financial planning horizon & {$[0.0001]$} & {$[0.0002]$} & {$[0.0001]^{\star *}$} \\
Long financial planning horizon & & & 0.033 \\
Observations & & & $0.067]$ \\
R-squared & & & 0.133 \\
\hline
\end{tabular}

Huber-White standard errors in brackets

${ }^{*}$ significant at $10 \%$; ${ }^{* *}$ significant at $5 \%$; ${ }^{* * *}$ significant at $1 \%$

\section{Table 8: Sensitivity analysis}

\begin{tabular}{|c|c|c|}
\hline & $\begin{array}{c}\text { Consumption } \\
\text { Change } \\
(1) \\
\end{array}$ & $\begin{array}{c}\text { Consumption } \\
\text { Change } \\
\text { (2) } \\
\end{array}$ \\
\hline Subjective mortality & $\begin{array}{l}-1.958^{* *} \\
(0.722)\end{array}$ & $\begin{array}{l}-1.917^{\star \star} \\
(0.700)\end{array}$ \\
\hline Health cost risk & $\begin{array}{l}0.0002^{\star *} \\
(0.0001)\end{array}$ & \\
\hline Health cost risk (low wealth) & & $\begin{array}{c}0.0003^{*} \\
(0.0001)\end{array}$ \\
\hline Health cost risk (high wealth) & & $\begin{array}{c}0.0001 \\
(0.0001)\end{array}$ \\
\hline Income (in \$1000) & $\begin{array}{l}-0.0003 \\
(0.0005)\end{array}$ & \\
\hline Total assets (in \$ 1000) & $\begin{array}{c}0.00004 \\
(0.00008)\end{array}$ & \\
\hline Good health & $\begin{array}{c}0.018 \\
(0.092)\end{array}$ & \\
\hline ADL change & $\begin{array}{c}0.067 \\
(0.054)\end{array}$ & \\
\hline Observations & 371 & 371 \\
\hline R-squared & 0.06 & 0.05 \\
\hline
\end{tabular}


Table 9: Estimated time discount rates and relative risk aversion parameters

Estimated relative risk aversion parameters

\begin{tabular}{lcc} 
& Point estimate & $25^{\text {th }}$ to $75^{\text {th }}$ Percentile \\
\hline Full sample & 0.503 & $0.404-0.658$ \\
High stated risk aversion & 0.741 & $0.517-1.112$ \\
Low stated risk aversion & 0.300 & $0.226-0.401$ \\
\hline
\end{tabular}

Estimated time discount rates

\begin{tabular}{lcc} 
& Point estimate & $25^{\text {th }}$ to $75^{\text {th }}$ Percentile \\
\hline Full sample & 0.043 & $0.031-0.061$ \\
Short financial planning horizon & 0.079 & $0.054-0.114$ \\
Medium financial planning horizon & 0.060 & $0.040-0.096$ \\
Long financial planning horizon & 0.003 & $-0.012-0.019$ \\
\hline
\end{tabular}


Figure 1: Distribution of subjective mortality rates and life table mortality rates

A) Subjective annual mortality rates

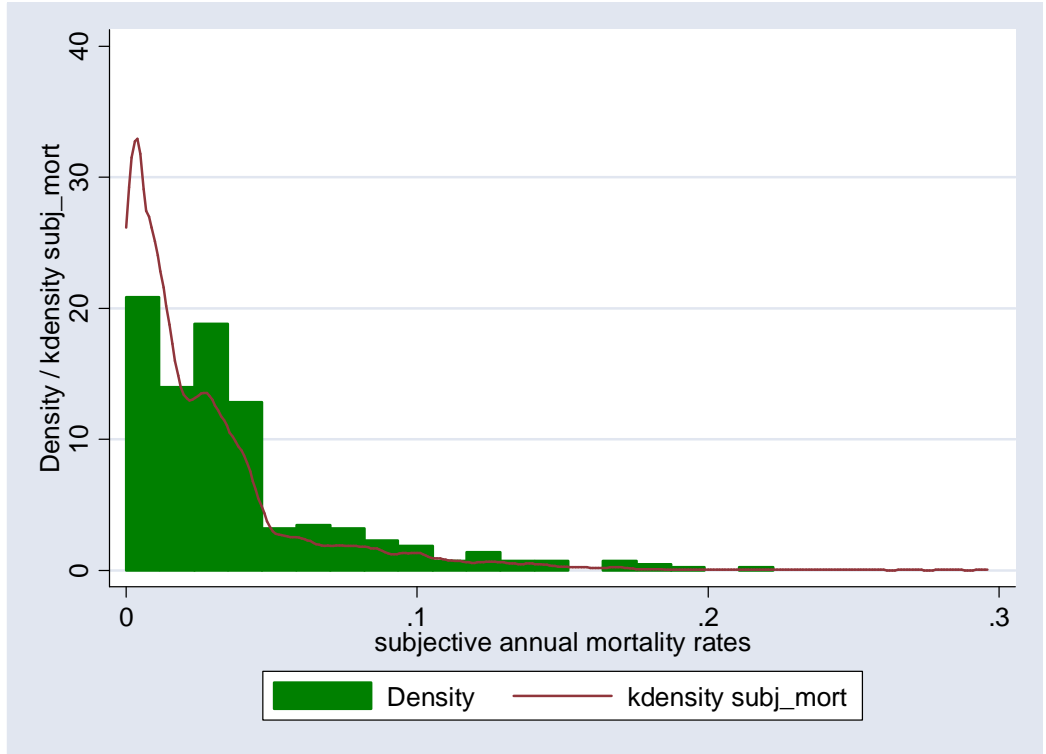

B) Life table annual mortality rates

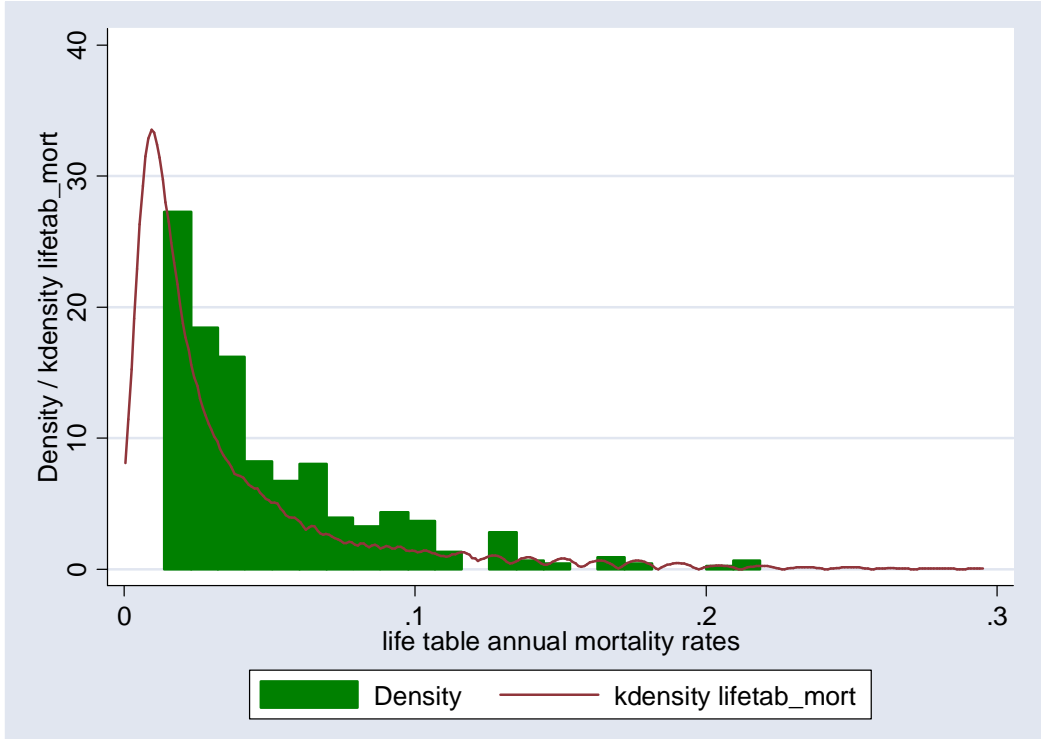

